\title{
Defensive Protectiontraditional Cultural Expresions (TCE) Masyarakat di Kabupaten Blora
}

\author{
Rinitami Njatrijani \\ Fakultas Hukum Universitas Dipoenegoro, Jl. Prof. Soedarto No. 1 Tembalang, Semarang \\ Email:njatrijani@yahoo.com
}

\begin{abstract}
Traditional Cultural Expressions (TCE) is all the intangible cultural heritage, developed by local communities, collectively or individually in a non-systemic manner and that are inserted in the cultural and spiritual traditions of the communities. The catagories of TK and TCE ... "expressions of folklore in the form of tekstual fonetic or verbal, music, dances, theater, fine art, ritual ceremony”. The legal framework of TCE in Indonesia that can be implemented as contained in the 1945 Constitution of the Republic of Indonesia (Fourth Amendment) Article 32 (1), Article 38 and 39 on Copyright Law Number 28 Year 2014 on Copyright, Law Number 5 Year 2017 on Futherance Culture, Presidential Regulation No.78 Year 2007 on the Convention on Protection of Intangible Cultural Heritage), Permendikbud N0.106 of 2013 on Intangible Cultural Heritage of Indonesia. Further provisions by the state are required to immediately ratify the Traditional Knowledge Bill and EBT into a separate law in Indonesia Defensive protection TCEin Blora community is urgent to be protected as a whole so as not to be abused by others. The process of recording, stipulating, proposing to the Indonesian Conservation Heritage Agency on ICH Unesco's list is the final process of digital documentation in the database of intangible cultural heritage as official data of the state which has a positive impact on the welfare of its supporting community. This research indicates that there are only 16 cultural works for the community in Blora Regency that have been designated as Indonesian Culture Heritage I Intangible Cultural Heritage in accordance with UNESCO Convention Year 2003. While there are still many cultural works that need to be prioritized for immediate recording for next year. (Barong, batik motif etc).
\end{abstract}

Keywords : Defensive Protection, Traditional Cultural Expressions (Tce), Misappropriation, Digital Document.

\begin{abstract}
Abstrak
TCE/Ekspresi budaya tradisional (EBT) adalah semua warisan budaya tak benda, yang dikembangkan oleh masyarakat lokal, secara kolektif atau individual dengan cara yang tidak sistemik dan disisipkan dalam tradisi budaya dan spiritual masyarakat. Kategori warisan budaya tak benda meliputi tradisi lisan, seni pertunjukkan, praktek-praktek sosial, ritual, perayaan-perayaan, pengetahuan dan praktek mengenai alam dan semesta atau pengetahuan dan ketrampilan untuk menghasilkan kerajinan tradisional. Kerangka
\end{abstract}


hukum EBT di Indonesia yang dapat diimplementasikn sebagaimana terdapat dalam UUD RI Tahun 1945 (Amandemen ke empat) Pasal 32(1), Pasal 38 dan 39 tentang Undang-undang Hak Cipta Nomor 28 Tahun 2014 tentang Hak Cipta, Undang-Undang Nomor 5 Tahun 2017 tentang Undang- Undang Pemajuan Kebudayaan yang lahir dalam rangka melindungi, memanfaatkan dan mengembangkan kebudayaan Indonesia, Perpres RI No.78 Tahun 2007 tentang Konvensi Perlindungan Warisan Budaya Takbenda), Permendikbud N0.106 Tahun 2013 tentang Warisan Budaya Takbenda Indonesia. Diperlukan ketentuan lebih lanjut oleh negara untuk segera mengesahkan RUU Pengetahuan Tradisional dan EBT menjadi Undang-Undang tersendiri di Indonesia.

Perlindungan defensif EBT di masyarakat Kabupaten Blora sangat mendesak untuk dilindungi secara keseluruhan agar tidak disalahgunakan oleh pihak lain. Proses pencatatan, penetapan, pengusulanke Badan Warisan Budaya Takbenda Indonesia dalam daftar ICH Unesco merupakanproses akhir dokumentasi secara digital dalam database warisan budaya takbenda sebagai data resmi negara yang memberikan dampak positif bagi kesejahteraan masyarakat pendukungnya.Penelitian ini menunjukkan bahwa baru ada 16 karya budaya bagi masyarakat di Kabupaten Blora yang telah ditetapkan sebagai Warisan Budaya Tak Benda Indonesia/Intangible Cultural Heritagesesuai Konvensi UNESCO Tahun 2003.Sementara masih banyak karya-karya budaya yang perlu diprioritaskan untuk segera dilakukan pencatatan untuk tahun-tahun mendatang.(Barong, motif batik dll).

Kata Kunci: Perlindungan Defensif, Ekspresi Budaya Tradisional (EBT), Penyalahgunaan, Dokumen Digital.

\section{PENDAHULUAN}

Traditional knowledge, genetic resources dan traditional cultural expression/ TCE/expression of folklore menjadi tiga isu penting berkaitan dengan perlindungan HKI dan banyak diperbincangkan baik pada level nasional maupun internasional. Johanna Gibson mengatakan bahwa isu perlindungan expression of folklore menjadi penting, karena expression of folklore tsb tidak hanya mempunyai dimensi seni dan budaya saja melainkan juga mempunyai dimensi sosial yang sangat kuat (Gibson:2004). ${ }^{1}$

Pengetahuan tradisional dalam hal ini diartikan sebagai pengetahuan yang dimiliki oleh suatu masyarakat selama turun-temurun, yang meliputi pengetahuan mereka tentang pengelolaan kekayaan hayati. Dalam beberapa tulisan pengetahuan tradisional ini lebih rinci lagi dibedakan dalam beberapa kategori sebagaimana yang terdapat dalam beberapa konsep rezim HKI. Misalnya pengelompokan dalam bidang pertanian, keilmuan atau ilmu pengetahuan, maupun folklore dan lain sebagainya.

\footnotetext{
${ }^{1}$ Budi Agus Riswandi, Direktur Pusat HKI FH UII Jogjakarta dalam Arif Lutfiansori, 2010, Hak Cipta Dan Perlindungan Folklore Di Indonesia, Yogyakarta: Graha Ilmu, halaman v.
} 
Tuntutan adanya perlindungan bagi pengetahuan tradisional muncul dengan Convention on Biological Diversity 1992(CBD). ${ }^{2}$ Sejak saat itu berbagai pertemuan tingkat dunia, terutama dalam kerangka World Intellectual Property Organization (WIPO) terus diselenggarakan untuk merumuskan sistem perlindungan yang tepat bagi pengetahuan tradisional tersebut. Indonesia sebagai salah satu negara yang kaya dalam keanekaragaman hayati dan keanekaragaman budaya di dunia serta sebagai peserta CBD dan anggota WIPO belum memiliki perundang-undangan yang khusus (sui generis) mengatur tentang pengetahuan tradisional dan ekspresi budaya tradisional, karena masih menjadi perdebatan panjang.

Menurut Convention on Biological Diversity (CBD), definisi Traditional Knowledge adalah pengetahuan, inovasi, danpraktik-praktik masyarakat asli dan lokal yang mewujudkan gaya hidup tradisional dan juga teknologi lokal dan asli yang status kedudukannya merupakan bagian tradisi masyarakat. ${ }^{3}$ World Intellectual Property Organization (WIPO) menggunakan istilah Traditional Knowledge untuk menunjuk pada kesusasteraan berbasis tradisi, karya artistik atau ilmiah, pertunjukan, invensi, penemuan ilmiah, desain, merek kolektif, nama dan simbol, informasi yang tidak diungkapkan, dan semua inovasi dan kreasi berbasis tradisi lainnya yang disebabkan oleh kegiatan intelektual dalam bidang-bidang industri, ilmiah, kesusasteraan atau artistik. Sedangkan menurut RUU PT dan EBT/ RUU Pengetahuan Traditional dan Ekspresi Budaya Tradisional, pengetahuan tradisional dan ekspresi budaya tradisional merupakan bagian dari identitas bangsa dan aset nasional yang harus dikembangkan, dilindungi, dipromosikan, dilestarikan dan dimanfaatkan, baik dalam skala lokal, nasional, maupun internasional untuk kesejahteraan rakyat Indonesia sebagaimana diamanatkan di dalam pembukaan UUD 1945.

WIPO mendefinisikan pemilik/pemegang traditional knowledgeyaitu semua orang yang menciptakan, mengembangkan, dan mempraktikkan traditional knowledge dalam aturan dan konsep tradisional. Masyarakat asli, penduduk, dan negara adalah pemilik traditional knowledge. Dengan demikian dalam perlindungan traditional

\footnotetext{
${ }^{2}$ Convention on Biological Diversity1992(CBD) 5 Juni 1992 telah diratifikasi oleh Indonesia dengan Undang-Undang Nomor 5 Tahun 1994 tentang Pengesahan United Nations Convention on Biological Diversity (Konvensi Perserikatan Bangsa-Bangsa mengenai Keanekaragaman Hayati) (LN.1994-41,TLN No.3556).

${ }^{3}$ Afrillyanna Purba, dkk., 2005, TRIPs-WTO Dan Hukum HKI Di Indonesia Kajian Perlindungan Hak Cipta Seni Batik Tradisional Indonesia, Jakarta: Asdi Mahasatya, halaman 36.
} 
knowledge ini yang dikedepankan adalah kepentingan komunal daripada kepentingan individual. Secara keseluruhan alasan utama memberikan perlindungan terhadap traditional knowledge yaitu: (1) pertimbangan keadilan; (2) konservasi; (3) memelihara budaya dan praktik (gaya hidup) tradisional; (4) mencegah perampasan oleh pihakpihak yang tidak berwenang terhadap komponen-komponen traditional knowledge; (5) mengembangkan penggunaan dan kepentingan traditional knowledge. ${ }^{4}$ Dalam konvensi ini secara resmi diakui bahwa pengetahunan tradisional (traditional knowledge) dan praktek-praktek yang dilakukan oleh masyarakat asli memiliki nilai komersial sehingga perlu mendapatkan perlindungan. ${ }^{5}$

Menyadari pluralitas budaya masyarakat lokal di Indonesia, maka peneliti memutuskan untuk mengangkat kondisi masyarakat di Kabupaten Blora, yang merupakan salah satu kabupaten yang memiliki lingkungan/kawasan hutan jati dengan luas wilayah $48 \%$ dari luas wilayahnya $1.820,588$ kilometer persegi. ${ }^{6}$ Selama ini hampir di sejumlah daerah di Jawa Tengah memiliki karya budaya takbenda yang merupakan faktor penting dalam mempertahankan keragaman budaya dalam menghadapi globalisasi yang berkembang. Pentingnya warisan budaya takbenda terletak pada kekayaan pengetahuan yang merupakan modal penting bagi pembangunan sosial dan ekonomi yang berkelanjutan bagi Indonesia untuk dikembangkan. Motif batik khas kabupaten Blora tidak hanya sebagai pola semata, guratan gambar dalam batik,tetapi Blora menyimpan makna yang mendalam seolah menggambarkan Blora, dengan seribu satu cerita.Hal ini menghasilkan motif khas batik Blora berupa desain pohon jati (daun jati, bunga/kembang jati/ bunga opo,batang/lingkar tahun pohon jati/kambium,biji jati/janggleng, ulat jati/ungker). Kesenian rakyat Blora yang mengandung pesanmoral bagus penting untuk menjaga budaya masyarakat tradisional Blora, antara lain: seni musik, seni tayub, seni teater rakyat, barongan, seni kethoprak,seniwayang, seni beladiri tradisional,peralatan dan persenjataan tradisional. Begitu pula makanan khas berupa sate ayam Blora, soto Klethuk, lontong tahu, nasi pecel Blora, ungker jati Blora dll. Di Kecamatan Cepu, Blora terdapat perusahaan minyak dan gas yang merupakan kekayaan sumber daya alam dan menginspirasibagi para pengrajin batik terhadapmotif/desainpompa angguk yang melekat pada motif batik tersebut. Selain itu

\footnotetext{
${ }^{4}$ Ibid, halaman 43 .

${ }^{5}$ Article 8(j) CDB 1994, da Silva, "The Protection of Intellectual Property", halaman 546.

${ }^{6}$ Ninuk Mardiana Pambudy, Avontur 24 jam Blora, Kompas, Minggu, 9 Juli 2017, halaman 29.
} 
terdapat masyarakat adat Samin atau Sedulur Sikep di Dukuh Blimbing, Desa Sambongrejo Kecamatan Sambong Kabupaten Blorajuga memiliki seni batik tulis karya warga desa adat Samin, dengan motif daun yang merambat, motif hewan dan pendopo Samin.

Batik merupakan budaya yang telah lama berkembang dan dikenal oleh Sejak di tetapkan sebagai global cultural heritage (warisan budaya dunia) oleh United Nation Education Scientifis And Cultural Organization (UNESCO) pada tanggal 2 Oktober 2009, masyarakat Indonesia harusnya lebih bangga dan melestarikan batik sebagai salah satu kekayaan bangsa. Dengan ditetapkannya hal tersebut, maka Indonesia menetapkan hari batik nasional sejak tangal 2 Oktober 2009. Penetapan tanggal tersebut dilaksanakan setelah diterbitkannya Keputusan Presiden No. 33 Tahun 2009 tentang Hari Batik Nasional oleh Presiden Susilo Bambang Yudhoyono pada tanggal 17 November 2009. Dari penetapan peraturan pemerintah ini disambut antusias oleh masyarakat. Salah satu ekspresi kegembiraan masyarakat adalah dengan dibuatnya batik di setiap daerah. Batik pada setiap daerah dibuat dengan inspirasi kekayaan yang ada di lingkungan sekitar maupun kebudayaan dari daerah tersebut. Hal ini sangat membantu dalam memperkenalkan kekayaan batik Indonesia di mata dunia.

Sebagai bagian dari pengetahuan tradisional (traditional knowledge), seni batik sudah dilindungi Undang-Undang Hak Cipta Indonesia lama (UUHC 1987, UUHC 1997, UUHC 2002) dan dalam UUHC 2014.

Dalam UUHC 2014 sebenarnya telah mengatur mengenai pencatatan karya cipta batik. Namun kenyataannya masih sedikit perusahaan yang melakukan pencatatan karya seni batik ke Ditjen HKI. Hanya perusahaan batik yang tergolong besar saja yang telah melakukan pencatatan karya cipta seni batiknya. Pada umumnya para pengusaha batik berpendapat bahwa pencatatan karya cipta batik bukan merupakan hal yang mendesak. Umumnya mereka mempersoalkan mahalnya biaya pencatatan, waktu yang lama, dan proses yang berbelit-belit. Selain itu pencatatan yang dilakukan tetap tidak mampu mencegah terjadinya peniruan atau penjiplakan terhadap karya cipta batik yang telah didaftar. Sementara bagi pengusaha batik yang tergolong menengah ke bawah (UKM), masih jarang sekali yang mendaftarkan karya seni batiknya. ${ }^{7}$

${ }^{7}$ Lilis, 2017, Wawancara, UKM Sekar Jompong, Jetis Blora, Semarang, Tri Lomba Juang: Parade UKM BRI, 5-7 Mei 2017. 
Di Blora sendiri para pengusaha batik masih banyak yang tergolong usaha menengah ke bawah (UKM). Para pemilik UKM hanya menganggap yang terpenting produknya laku terjual, dan belum memikirkan pentingnya kegunaan hak cipta bagi produk yang telah dihasilkan. Apabila dikaitkan dengan konsep traditional knowledge, jarang ditemukan kepemilikan batik secara individual, tetapi yang dikedepankan adalah kepentingan komunal dari masyarakat yang menghasilkan traditional knowledge daripada kepentingan individual.

Baik dalam sistem hukum nasional maupun internasional traditional knowledge belum memiliki bentuk perlindungan tersendiri. Walau belum terbentuk sistem HKI bagi traditional knowledge secara tersendiri, tidak menghalangi upaya dalam perlindungan traditional knowledge. Misalnya di Indonesia berkaitan dengan seni batik yang dapat dikategorikan sebagai kreasi yang dihasilkan dengan menggunakan traditional knowledge masyarakat Indonesia, maka seni batik tradisional telah menjadi milik seluruh masyarakat Indonesia. Perlindungan yang diberikan bukan hanya terbatas pada seni batik saja, melainkan juga bagi pengetahuan tradisional dan ekspresi budaya tradisional/folklor serta seluruh hasil kebudayaan rakyat yang menjadi milik bersama bangsa Indonesia.

Melakukan inventarisasi terhadap batik sebagai bagian traditional knowledge(TK) dan traditional cultural expression (TCE) sangat penting dilakukan. Inventarisasi merupakan salah satu langkah Defensive protection. ${ }^{8}$ Defensive protection adalah perlindungan yang dimaksudkan tidak untuk melindungi sebagaimana traditional knowledge yang berlaku di rezim HKI. Perlindungan secara defensif hanya dimaksudkan sebagai upaya agar tidak terjadi penggunaan secara melawan hukum terhadap pengetahuan traditional tertentu yang dimiliki oleh suatu masyarakat oleh pihak lain. Langkah-langkah yang dilakukan oleh berbagai negara dan komunitas masyarakat dalam memanfaatkan defensive protection ini adalah dengan membangun database berkaitan dengan pengetahuan tradisional dan ekspresi budaya tradisional. Sehingga sistem database kebudayaan yang terpadu ini dapat digunakan sebagai proses akhir inventarisasi yang kemudian didokumentasikan secara sistematis dalam sebuah database tersebut. ${ }^{9}$

\footnotetext{
${ }^{8}$ Arif Lutfiansori, 2010, Hak Cipta Dan Perlindungan Folklore Di Indonesia, Yogyakarta: Graha Ilmu, halaman 146.

${ }^{9}$ Ibid.
} 
Proses inventarisasi ini idealnya dilakukan oleh lembaga yang secara implisit disebutkan sebagai lembaga representasi negara dalam hal ini Direktorat Warisandan Diplomasi Budaya Kementrian Pendidikan dan Kebudayaan. Walau bagaimanapun perlu juga digalakkan, dikembangkan, dan ditumbuhkan semangat bagi masyarakat luas untuk melakukan proses inventarisasi. Dalam hal ini terdapat berbagai strategi yang dapat dilakukan oleh seluruh unsur masyarakat sesuai dengan peran dan fungsinya masing-masing sehingga proses inventarisasi tidak hanya dibebankan sepenuhnya kepada pemerintah.

Pertama adalah memberikan pemahaman kepada masyarakat adat dan para seniman maupun pengusaha mengenai akan arti penting pengetahuan traditional dan ekspresi budaya tradisional. Kedua adalah memanfaatkan kesenian tradisional secara optimal dengan menghormati hak-hak sosial dan budaya masyarakat yang berkepentingan. Ketiga adalah melakukan dokumentasi yang komprehensif. Dokumetasi digital yang memadai diakses oleh pihak lain atas pengetahuan tradisional dan ekspresi budaya tradisional di Indonesia tersebut berfungsi sebagai mekanisme perlindungan defensif (defensiveprotection) untuk menanggulangi penyalahgunaan (misappropriation) instrumen HKI terhadap folklor Indonesia di luar negeri. ${ }^{10}$

Fakta dan permasalahan hukum yang terjadi di Indonesia sebagai negara berkembang yang mempunyai kekayaan berlimpah ruah mengenai pengetahuan tradisional dan folklor serta indikasi geografis, tetapi permasalahan yang ada bangsa kita belum maksimal dalam mengembangkan potensi yang dimiliki, karena lemahnya pengetahuan, skill, profesionalisme sumber daya manusia dan dana. Kondisi inilah justru dimanfaatkan oleh negara maju yang mempunyai kelebihan teknologi, kemampuan finansial, teknis, dan melalui mekanisme beroperasinya berbagai perusahaan multinasional, yang mengakibatkan keragaman pengetahuan tradisional dan budaya yang terbesar dimiliki oleh Indonesia menjadi sasaran utama pembajakan pihak asing. Pengambilan secara tidak sah (misappropriation) pengetahuan tradisional dan budaya yang terjadi di beberapa daerah selama ini dilakukan dengan cara "berkedok" kerja sama penelitian. Pengetahuan tradisional itu sangat luas dapat meliputi bidang teknologi, seni, pangan, obat, seni tari, musik, desain dari masyarakat.

\footnotetext{
${ }^{10} \mathrm{Ibid}$, halaman 147-148.
} 


\section{Permasalahan}

Bertolak dari latar belakang dan fokus studi tersebut di atas, maka ada dua (2) permasalahan dalam penelitian yang layak dikaji, yaitu:

1. Bagaimana defensive protection terhadap traditional cultural expressions (TCE)yang dimiliki oleh masyarakat di Kabupaten Blora ?

2. Bagaimana upaya agar tidak terjadi penggunaan secara melawan hukum terhadap traditional cultural expressions (TCE) yang dimiliki masyarakat di Kabupaten Blora oleh pihak lain?

\section{Metode Penelitian}

Pendekatan dalam penelitian ini dikategorikan pendekatan socio- legal dan pendekatan ini dilakukan untuk memahami hukum dalam konteks masyarakatnya ${ }^{11}$ yaitu pendekatan yang bersifat non doktrinal. Dalam mencapai tujuan penelitian ini dipilihlah lokasi yang masyarakatnya mempunyai potensi menghasilkan kreativitas intelektual berbasis tradisi dengan seting sosial adalah masyarakat yang masih memegang tradisi, nilai dan norma adatdalam hal ini masyarakat kabupaten Blora.

- Data yang diperoleh dianalisis secara kualitatif, yaitu analisis yang dilakukan dengan memahami dan merangkai data yang telah diperoleh di lapangan, yang dilakukan melalui pengelompokkan data dan disusun sistematis, kemudian ditarik kesimpulan. Kesimpulan yang diambil dengan menggunakan cara berpikir induktif ${ }^{12}$, yaitu dengan cara berpikir yang mendasarkan pada hal-hal yang bersifat khusus, kemudian ditarik kesimpulan yang bersifat umum.

\section{Kerangka Teori}

\section{Penggunaan Istilah EBT dan Folklor}

Awal perlunya perlindungan terhadap EBT berasal dari istilah "traditional cultural expression" menggunakan istilah "expression of folklore". Istilah "folklor" biasanya dimaksudkan terhadap segala hasil budaya yang tidak dianggap standar

\footnotetext{
${ }^{11}$ Soerjono Soekanto dkk, 1988, Pendekatan Sosiologi Terhadap Hukum, Jakarta, PT Bina Aksara, halaman 9.

${ }^{12}$ Sudarto, 2002, Metode Penelitian Filsafat, Jakarta, Raja Grafindo, halaman 57.
} 
"savage", "primitive" atau "belum beradab" terutama ketika berhadapan dengan kebudayaan Eropa pada awal perkembangan ilmu pengetahuan terutama dalam kajian Etnologi (Ilmu Bangsa-Bangsa) yang sekarang disebut antropologi. ${ }^{13}$

James Danandjaja ${ }^{14}$ mengemukakan ciri-ciri pengenal utama pada folklor pada umumnya yang dapat dirumuskan sebagai berikut :

a. Penyebaran dan pewarisannya biasanya dilakukan secara lisan.

b. Folklor bersifat tradisional

c. Folklor ada (eksis) dalam versi-versi bahkan varian-varian yang berbeda.

d. Folklor bersifat anonim, yaitu nama penciptanya sudah tidak diketahui orang lagi;

e. Folklor biasanya mempunyai bentuk berumus atau berpola, dan selalu menggunakan kata-kata klise;

f. Folklor mempunyai kegunaan (function) dalam kehidupan bersama suatu kolektif.

g. Folklor bersifat pralogis yaitu mempunyai logika sendiri yang tidak sesuai dengan logika umum.

h. Folklor menjadi milik bersama(collective) dari kolektif tertentu.

i. Folklor pada umumnya bersifat polos dan lugu, sehingga seringkali kelihatannya kasar, terlalu spontan.

Menurut Jan Harold Brunvand ${ }^{15}$ seorang ahli folklor dari AS dalamJames Danandjaja, folklor dapat dibagi dalam tiga kelompok besar, yang didasarkan pada unsur-unsur kebudayaan yang menjadi ciri khasnya. Kelompok tersebut terdiri dari:

a. Folklor Lisan (verbal folklore) adalah folklor yang bentuknya memang murni lisan. Bentuk-bentuk (genre) folklor yang termasuk ke dalam kelompok besar ini antara lain yang diperinci lagi dalam bentuk genre :

1) Bahasa rakyat (folk speech), seperti logat, julukan, pangkat tradisional dan titel kebangsawanan;

2) Ungkapan tradisional, seperti peribahasa, pepatah dan pameo;

3) Pertanyaan tradisional (seperti teka-teki);

\footnotetext{
${ }^{13}$ Edy Sedyawati, 2003, Budaya Indonesia Kajian Arkeologi, Seni dan Sejarah, PT Rajawali Pers, Jakarta, halaman 1.

${ }^{14}$ James Danandaja, 1991, Folklor Indonesia Ilmu Gosip, dongeng dan lain-lain, Jakarta: Pustaka Utama Grafiti, Cetakan ketiga, halaman 3-5.

${ }^{15}$ Jan Harold Brunvand, 1978, The Study of American Folklor an Introduction, 2nd, New York, W.W. Norton \&Co Inc dalam James Danandjaya,1991, Folklor Indonesia Ilmu Gosip, dongeng dan lain-lain, Jakarta: Pustaka Utama Grafiti, Cetakan ketiga, halaman 21-22.
} 
4) Nyanyian rakyat (seperti balada, epos, wira cerita);

b. Folklor sebagian (partly verbal folklore) yaitu permainan rakyat, teater rakyat, makanan dan minuman rakyat, kepercayaan dan keyakinan rakyat.

c. Folklor bukan lisan( non verbal folklore), yang diperinci lagi dalam sub kelompok:

1) Material ( seperti arsitektur rakyat, seni kriya rakyat, pakaian dan perhiasan tubuh rakyat dan obat-obatan rakyat);

2) Non Material ( seperti gerak isyarat tradisional rakyat dan bunyi-bunyian rakyat);

Fungsi folklor sebagai berikut : (a) Sebagai prinsip-prinsip proyeksi yakni sebagai alat pencermin angan-angan suatu kolektif; (b) Sebagai alat pengesahan pranata-pranata dan lembaga-lembaga kebudayaan, (c) Sebagai alat pemaksa dan pengawas agar norma-norma masyarakat akan selalu dipatuhi anggota kolektifnya. ${ }^{16}$

\section{Pengertian Ekspresi Budaya Tradisional (EBT)}

Ekspresi Budaya Tradisional (EBT) adalah segala bentuk ekspresi/ keseluruhan kreativitas intelektual yang merupakan ungkapan/ ekspresi ide, gagasan, tindakan dan hasil karya manusia sebagai ungkapan tradisi turun- temurun dalam masyarakat yang menunjukkan keberadaan suatu budaya mempunyai ciri atau karakteristik :

a) Berakar pada identitas sosial dan budaya komunitas masyarakat tradisional/komunitas budaya lokal ataupun komunitas masyarakat bangsa;

b) Memiliki indikasi sebagai suatu warisan budaya;

c) Pembuatnya anonim (author unknown) atau/ dan oleh individu-individu dalam masyarakat secara bersama-sama memiliki hak, tanggung jawab maupun ijin untuk melakukan itu;

d) Diciptakan bukan untuk tujuan komersiil, namun sebagai bentuk ekspresi keagamaan ataupun ekspresi kebudayaan.

e) Dipelihara, dipertahankan, digunakan dan dikembangkan oleh masyarakat adat atau komunitas budaya lokal ataupun komunitas bangsa.

\section{Pendekatan Perlindungan terhadap Ekspresi Budaya Tradisional (EBT)}

EBT merupakan istilah yang digunakan WIPO dalam berbagai forum

\footnotetext{
${ }^{16}$ Ibid, halaman 2.
} 
internasional. Pemaknaan EBT yang dikemukakan oleh WIPO ditujukan umtuk memberikan garisan terhadap suatu karya budaya yang bersifat tradisional dan dimiliki oleh suatu masyarakat tradisional sebagai karya intelektual yang berasal dari kebudayaan tradisional milik kelompok masyarakat tradisional.Pemberian makna tersebut akan menjadi acuan untuk menetapkan suatu karya intelektual dari budaya tradisional merupakan suatu ciptaan dalam bidang seni yang mengandung dan mengkaitkannya pada satu kelompok masyarakat sebagai pengemban. ${ }^{17}$ Eddy Damian berpendapat bahwa ekspresi budaya tradisional merupakan suatu ciptaan dalam bidang seni yang mengandung unsur karakteristik warisan tradisional sebagai kultur bangsa yang merupakan sumber daya bersama dikembangkan dan dipelihara atau dilestarikan oleh komunitas atau masyarakat tradisional tertentu atau organisasi sosial tertentudalam kurun waktu secara berkesinambungan. ${ }^{18}$ EBT bersifat "relegio magis agraris rural" merupakan bentuk material yang berkembang dari generasi ke generasi dan bukan kebaharuan, hanya berupa pengulangan, diampu secara komunal dan tidak selalu bermakna dalam budaya industri. ${ }^{19}$

\section{Justifikasi Perlindungan Hukum Terhadap EBT}

Pada saat ini perlindungan terhadap EBT mendasarkan pada prinsip-prinsip HKI ( hukum hak cipta dan hukum kekayaan industri)yang sekarang masih berlaku baik di tingkat nasional maupun internasional. Di samping itu perlindungan EBT juga mendasarkan pada prinsip-prinsip di luar HKI yaitu ketentuan hukum perlindungan warisan budaya dan ketentuan hukum HAM. Sebagaimana Pasal 27 Deklarasi Universal Hak Asasi Manusia (Universal Declaration of Human Rights / DUHAM 1948 ) memuat ketentuan bahwa setiap orang mempunyai hak perlindungan atas kepentingan moral dan material terhadap karya seni dan ilmu pengetahuan yang diciptakan. ${ }^{20}$

\footnotetext{
${ }^{17}$ Bayu Akbar W, 2016, Perlindungan Hukum Terhadap EBT oleh Negara Sebagai Pemegang Hak Cipta Kekayaan Komunal Masyarakat, FH Unsoed.

${ }^{18}$ Eddy Damian, 2012, Glosarium Hak Cipta dan Hak Terkait, Bandung, Alumni, halaman 29-30.

${ }^{19}$ Miranda Risang Ayu, Harry Alexander, Wina Puspitasari, 2010, Hukum Sumber Daya Genetik, Pengetahuan Tradisional dan EBT, Bandung, Alumni, halaman 5.

${ }^{20}$ Pasal 27 Deklarasi Hak Asasi Manusia; (1) Setiap orang berhak untuk turut serta dalam kehidupan kebudayaan masyarakat dengan bebas, untuk menikmati kesenian, dan untuk turut mengecap kemajuan dan manfaat ilmu pengetahuan. (2) Setiap orang berhak untuk memperoleh perlindungan atas keuntungan-keuntungan moril maupun materiil yang diperoleh sebagai hasil karya ilmiah, kesusasteraan atau kesenian yang diciptakannya.
} 


\section{a. Perlindungan Ekspresi Budaya Tradisional/ EBT melalui Hak Cipta ${ }^{21}$}

Prinsip Hak Cipta yang terdapat dalam The Berne Convention for The Protection of Literary and Artistic Works (Konvensi Berne 1967yang telah diamandemen pada 28 September 1979)Article 7:3 mengatur konsep kepemilikan terhadap karya cipta anonim atau "Anonymous Works". Meskipun tidak secara khusus mengatur mengenai perlindungan EBT, ketentuan dalam Konvensi Bern 1967 ini dapat diterapkan dalam EBT yang tidak diketahui penciptanya. Hal ini dapat kita pahami dari Berne Convention for the Protection of Literary and Artistic Works(Konvensi Berne 1967 yang telah diamandemen pada 28 September 1979) Article 15 Paragraf 4 (a):

In the case of unpublished works where the identify of the author is unknown, but where there is every ground to presume that he is a national of a country of the Union, it shall be a matter for legislation in that country to designate the competent authority which shall represent the author and shall be entitled to protect and enforce his rights in the countries of the Union. Paragraf 4 (b) Countries of the Union which make such designation under the terms of this provision shall notify the Director General by means of a written declaration giving full information concerning the authority thus designated. The Director General shall at once communicate this declaration to all other countries of this Union.

Ketentuan tersebut walaupun secara implisit tidak menyebutkan perlindungan terhadap EBT, tetapi ketentuan perlindungan terhadap karya yang tidak diketahui penciptanya (anonymous author) dapat dianalogikan sebagai karya cipta yang mempunyai karakter EBT. Ini merupakan langkah awal memberikan perlindungan hukum terhadap EBT.

Indonesia sebagai negara yang telah meratifikasi Konvensi Bern dan TRIP's (Trade Related Aspects Of Intellectual Property) mempunyai kewajiban penuh untuk mengimplementasikan prinsip-prinsip perlindungan hukum terhadapanonymous works(ciptaan yang penciptanya tidak diketahui) yang ada dalam Konvensi Bern ke dalam Undang-Undang Hak Cipta Nomor 28 Tahun 2014 pada Pasal 38 ayat (1),(2),(3) dan (4) sebagai berikut:

(1) Hak Cipta atas ekspresi budaya tradisional dipegang oleh Negara.

(2) Negara wajib menginventarisasi, menjaga, dan memelihara ekspresi budaya tradisional sebagaimana dimaksud pada ayat (1).

\footnotetext{
${ }^{21}$ Kholis Roisah,2014, Perlindungan Ekspresi Budaya Tradisional Dalam Sistem HKI, Jurnal MMH, Jilid 43 Nomor:3, Juli 2014, halaman 374.
} 
(3) Penggunaan ekspresi budaya tradisional sebagaimana dimaksud pada ayat (1) harus memperhatikan nilai-nilai yang hidup dalam masyarakat pengembannya.

(4) Ketentuan lebih lanjut mengenai hak cipta yang dipegang oleh negara atas ekspresi budaya tradisional sebagaimana dimaksud pada ayat (1) diatur dengan Peraturan Pemerintah.

Demikian pula dalam penjelasan Pasal 38 ayat (1) juga telah diberikan batasan mengenai apakah yang dimaksud dengan "ekspresi budaya tradisional", yaitu segala sesuatu yang mencakup salah satu atau kombinasi bentuk ekspresi sebagai berikut:

a. Verbal tekstual, baik lisan maupun tulisan, yang berbentuk prosa maupun puisi, dalam berbagai tema dan kandungan isi pesan, yang dapat berupa karya sastra ataupun narasi informatif;

b. Musik, mencakup antara lain, vokal, instrumental, atau kombinasinya;

c. Gerak, mencakup antara lain, tarian;

d. Teater, mencakup antara lain, pertunjukkan wayang dan sandiwara rakyat;

e. Seni rupa, baik dalam bentuk dua dimensi maupun tiga dimensi yang terbuat dari berbagai macam bahan, seperti: kulit, kayu, bambu, logam, batu, keramik, kertas, tekstil, dan lain-lain atau kombinasinya; dan

f. Upacara adat.

Rumusan tersebut di atas dinilai oleh banyak kalangan masih minim untuk menjadi satu konsep perlindungan folklor. Hawin, guru besar dari Universitas Gajahmada, mengatakan bahwa pengaturan folklor yang masih dalam beberapa pasal dan abstrak masih belum dapat digunakan sebagai acuan untuk perlindungan folklor. ${ }^{22}$ Ketentuan tersebut di atas jika diimplementasikan dalam praktek pada perlindungan EBT tidak mudah dilakukan. Ada tiga alasan yang menjadi penyebabnya, pertama definisinya mengandung rumusan yang kurang jelas; kedua belum diaturnya prosedur untuk membedakan ciptaan yang masuk kategori ekspresi budaya tradisional dengan ciptaan yang bukan ekspresi budaya tradisional; ketiga tidak memberikan informasi terkait lembaga pelaksana yang berwenang untuk menetapkan suatu ciptaan sebagai karyakarya EBT tersebut ${ }^{23}$. Pasal 38 UU Nomor 28 Tahun 2014 tentang Hak Cipta tersebut masih sulit untuk diimplementasikan sebagaiman tertera ayat 4 pasal tersebut bahwa

\footnotetext{
${ }^{22}$ Arif Lutviansori, op.cit, halaman115.

${ }^{23}$ Mencari Format Kebijakan Hukum Yang Sesuai Untuk Perlindungan Folklor di Indonesia, diakses pada Selasa, 21 Agustus 2017, pukul 16.07.
} 
ketentuan lebih lanjut mengenaihak cipta yang dipegang oleh negara atas ekspresi budaya tradisional sebagaimana dimaksud pada ayat (1) diatur dengan Peraturan Pemerintah, namun faktanya kini belum ada Peraturan Pelaksananya. Di tingkat nasional sejak tahun 2008 Indonesia telah memulai proses penyusunan Rancangan Undang-Undang (RUU) sui generis untuk melindungi penggunaan kekayaan intelektual yang ada pada Pengetahuan Tradisional dan Ekspresi Budaya Tradisional Indonesia, namun sampai sekarang belum disahkan sebagai Undang-Undang.Lahirnya UndangUndang Nomor 5 Tahun 2017 tentang UU Pemajuan Kebudayaan mempunyai beberapa manfaat bagi masyarakat yaitu $:^{24}$

a. Kebudayaan merupakan investasi masa depan dalam membangun peradaban bangsa.

b. Perlu dibangun sistem pendataan kebudayaan terpadu yang isinya terkait obyek kemajuan kebudayaan, sumber daya manusia kebudayaan, lembaga kebudayaan, pranata, sarana dan prasarana serta data lain terkait kebudayaan.

c. Perlunya pokok pikiran kebudayaan daerah (obyek pemajuan kebudayaan) baik tradisi lisan, manuskrip adat istiadat, ritus, pengetahuan tradisional, seni, bahasa, permainan rakyat hingga olahraga tradisional yang disusun oleh para budayawan, pegiat budaya dan pemangku kepentingan dalam rangka memajukan kebudayaan daerahnya.

d. Perlunya Indonesia memiliki strategi kebudayaan yang disusun oleh pemerintah pusat dengan melinatkan masyarakat yang memiliki kreibilitas dan kompetensi di bidangnya.

e. Perlunya dibuat rencana induk pemajuan kebudayaan yang menjadi dasar dalam penyususnan rencana pembangunan jangka panjang dan menengah

f. Perlu diatur pemanfaatan kemajuan kebudayaan yang akan dimanfaatkan oleh industri besar dan atau pihak asing yang akan memanfaatkan objek pemajuan kebudayaan bagi kepentingan komersial terkait pembagian manfaat dan pencantuman asal-usul obyek pemajuan kebudayaan.

g. Perlunya penghargaan terhadap orang/pihak yang berkontribusi atau berprestasi luar biasa dalam pemajuan kebudayaan.

h. Perlunya diatur pemberian sanksi terhadap orang yang melawan hukum, menghancurkan dan merusak/ menghilangkan atau mengakibatkan sistem pendataan

\footnotetext{
${ }^{24}$ Ketua Komisi X DPR RI, www.jogloabang.com. Rapat Paripurna DPR RI, 28 April 2017.
} 
kebudayaan terpadu tidak dapat berfungsi sebagaimana mestinya.

Sebagian besar karya EBT/folklore merupakan karya yang mempunyai nilai seni yang tinggi dan tingkat kerumitan yang sangat kompleks serta proses menuangkan kreasinya memerlukan waktu yang lama dan kapasitas spiritual yang bagus pula. Karakter EBT merupakan suatu karya cipta yang proses kreasinya berlangsung dalam waktu yang lama, lintas generasi dan sulit untuk menentukan siapa pemegang hak ciptanya.

Dari karya-karya EBT sebagianbersifat tertutup dan rahasiayang hanya digunakan untuk tujuan tradisi ritual komunitasnya itu sendiri. Ini bertujuan untuk menjaga kesucian/kesakralan dari karya/ pengetahuan EBT yang diyakini oleh masyarakat/komunitas tersebut. Ketika karya EBT digunakan di luar komunitasnya dan tidak sesuai dengan tradisi, maka makna kesakralannya akan hilang dan membuat tidak nyamannya komunitas tersebut. Inilah yang disebut dengan kerugian moral bagi komunitas pemilik EBT tersebut atau kerugian yang bersifat non economic interest. Oleh karena itu EBT relevan dilindungi prinsip Hak Cipta, karena di dalamnya terkandung hak ekonomi dan hak moral sekaligus. Pada hak moral terkandung (a) Hak untuk memperoleh pengakuan publik sebagai pencipta atas suatu karya untuk mencegah pihak lain mengklaim karya tersebut, atau juga untuk mencegah pihak lain tanpa seijin pencipta, (b) Hak integritas, yaitu hak untuk mengajukan keberatan atas perubahan yang dilakukan terhadap suatu karya tanpa sepengetahuan si pencipta.

Hak moral atas EBT yaitu hak untuk disebutkan sumber atribusi ( hak atas identitas sebagai pencipta), klaim kepemilikan dan hak untuk mencegah pengakuan kepemilikan pihak lain atas karya EBT; hak atas penghormatan untuk mencegah modifikasi, mutilasi, perubahan dan distorsi atas karya EBT dan hak untuk membuka serta mengumumkan (hak kapan dan bagaimana suatu karya EBT bisa dibuka untuk publik). ${ }^{25}$

\footnotetext{
${ }^{25}$ Konvensi Bern Pasal 6 bis, Moral Rights, Article (1 ) Independently of author's economic rights, and even after the transfer of said rights, the author shall have the right to claim authorship of the work and to object to any distortion, mutilation or other modification of, or other derogatory action in relation to, the said work, which would be prejudicial to his honor or reputation.
} 


\section{b. Perlindungan EBT melalui Hak Terkait ${ }^{26}$}

Perlindungan internasional terhadap EBT termuat dalam (WPPT) yaitu perjanjian internasional yang ditandatangani oleh negara-negara anggota WIPO disepakati di Genewa pada tanggal 13- 21 Juni 2002. WPPT turut memberikan perlindungan terhadap EBT, mengingat tarian tradisional, puisi, drama, lagu dan musik serta berbagai bentuk kesenian tradisional lainnya muncul sebagai bagian dari pertunjukkan hidup (live performance) yang ditampilkan. Definisi penampil menurut Pasal 2 (a) WPPT sebagai berikut :

"performers" are actors, singers, musicians, dancers, and other persons who act, sing, deliver, declaim, play in, interpret, or otherwiseperform literary or artistic works or expressions of folklore;"

Secara tidak langsung dengan melihat definisi tersebut di atas, maka WPPT turut memberikan perlindungan terhadap seniman tradisional yang menampilkan pertunjukkan Ekspresi Budaya Tradisional. Perlindungan EBT dalam WPPT diberikan dengan anggapan bahwa suatu karya seni pertunjukkan merupakan bagian yang tak terpisahkan dari penampilnya. Perlindungan terhadap hak penampil ini juga mempunyai jangka waktu perlindungan yang telah ditentukan sebelumnya. Pada sisi yang lain perlindungan yang diberikan terhadap EBT masih terbatas pada lingkup "phonogram" yang didifinisikan "the fixation of the sounds of performance or of other sounds, or of a representation of sounds, other than in the form of a fixation incorporated in a cinematographic or other audovisual work". (Article 2 (b) WIPO Performences and Phonogram Treaty, 1996). Sementara itu EBT seringkali tidak memiliki bentuk "fixation", yang menurut Rahmi Janet ${ }^{27}$ EBT berangkat dari tradisi lisan ( tidak tertulis dan tidak terekam ) yang sangat potensial untuk dilindungi dengan hak terkait untuk penampilannya karena adanya pengkomunikasian pada masyarakat atau bahkan di pasarkan ke luar negara. Jadi perlindungan hak terkait dengan hak cipta untuk ekspresi budaya tradisional ${ }^{28}$ mempunyai dua (2) tujuan sekaligus sebagai sarana untuk melestarikan EBT dan sebagai sarana promosi untuk pengomersialannya di pasar internasional.

\footnotetext{
${ }^{26}$ Kholis Roisah,op.cit, halaman 376.

${ }^{27}$ Rahmi Janet, 2014, Hukum Hak Cipta (Copyright's Law), Bandung, PT Citra Aditya Bakti, halaman 253.

${ }^{28} \mathrm{Ibid}$, halaman 253.
} 


\section{c. Perlindungan EBT melalui Prinsip Perlindungan HKI Terpadu}

Perlindungan EBT melalui prinsip perlindungan HKI terpadu artinya bahwa dalam EBT terkandung prinsip HKI yang melindungi paten, merek dagang dan desain indutri ${ }^{29}$ dengan mendasarkan pada Paris Convention on Industrial Property Protection 1883. Dapat dimungkinkan bahwa suatu kreasi yang mempunyai motif tradisional ( motif ukir kayu, motif/desain kain batik, bordir, peralatan kesenian dan persenjataan tradisional, peralatan transportasi tradisional, tenun dan sebagainya) dilindungi berdasarkan hukum desain industri.Begitu pula prinsip perlindungan merk kolektif, dimana pendaftarannya dilakukan manakala EBT digunakan sebagai produk dalam aktivitas komersial oleh asosiasi dari komunitas dimana EBT berasal. Prinsip perlindungan merk kolektif memberi keuntungan yaitu menandakan keasliansuatu produk EBT serta membantu konsumen akan identitas asli produk EBT. Pendaftaran ini juga menunjukkan siapa yangmembuat dan produk EBT berasal dan sekaligus mempromosikan industri produk berbasis EBT.

Peluang perlindungan EBT melalui indikasi sebagai penanda asal dari suatu barang telah diatur secara implisit di dalam Konvensi Paris revisi tahun 1979 padaarticle 10. Berdasarkan konvensi ini bahwa setiap negara wajib melindungi produsen (producer), pembuat (manufacturer) maupun pedagang (merchant) dari penggunaan indikasi palsu (falseindication) terhadap sebuah barang. Prinsip ini dimungkinkan untuk memberikan perlindungan terhadap EBT, karena karakteristik karya atas EBT mempunyai keterkaitan dengan pengetahuan atau tradisi budaya yang tidak lepas dari sifat geografis asalnya. Seperti kata untuk Barong, kethoprak, hadroh/rebana, karawitan,desain/motif khas batik berupa pohon jati (daun, bunga, maupun batang), satai, soto Klethuk mengindikasikan daerah Blora. Begitu puladi Kecamatan Cepu, Blora juga terdapat perusahaan minyak dan gas yang kita kenal dengan desain pompa angguknya jika melekat pada motif batik, selain itu terdapat masyarakat adat Samin atau Sedulur Sikep di Dukuh Blimbing, Desa Sambongrejo Kecamatan Sambong Kabupaten Blora.

Perlindungan terhadap karya EBT berdasarkan ketentuan Pasal 56 ayat (1) UUM 2001, Indikasi Geografis dilindungi sebagai tanda yang menunjukkan daerah asal barang, yang karena faktor lingkungan geografis termasuk faktor alam, faktor manusia

\footnotetext{
${ }^{29}$ Kholis Roisah, Perlindungan Ekspresi Budaya Tradisional Dalam Sistem Hukum Kekayaan Industri, Jurnal MMH, 2014.
} 
atau kombinasi dari kedua faktor tersebut memberikan ciri dan kualitas tertentu pada barang yang dihasilkan. Oleh karena itu suatu indikasi geografis dapat melibatkan pengetahuan tradisional, yaitu pengetahuan yang dimiliki oleh sekelompok masyarakat tempat penghasil produk EBT tersebut. Namun penggunaan indikasi geografis sebagai alternatif perlindungan EBT tidak luput dari kesulitan. ${ }^{30}$ Pertama IG hanya melindungi EBT yang memiliki bentuk nyata sebagai sebuah barang atau produk yang dikomersialkan. Sementara IG tidak dapat digunakan untuk melindungi EBT dalam bentuk ekspresi seni atau musikal yang bersifat lisan. Kedua IG tidak mengatur kompensasi oleh pihak pemakai suatu produk EBT dengan masyarakat adat asal EBT tersebut.

Perlindungan EBT terhadap produk yang berkaitan denganrahasia dagang seperti pengetahuan tentang obat-obatan yang dimiliki oleh masyarakat tradisional, dimungkinkan diberi perlindungan melalui rezim rahasia dagang. Perlindungan EBT terhadap hukum paten mengalami kendala, karena prinsip novelty ( kebaharuan) tidak terpenuhi, dan kebanyakan EBT dan pengetahuan tradisional digunakan selama berabad-abad dan turun- temurun oleh masyarakat tradisional, sehingga sulit juga untuk menemukan siapa penemu sebenarnya dari pengetahuan tradisional tersebut. Begitu pula persyaratan formal untuk mendapatkan perlindungan paten, penemuannya harus diuraikan secara tertulis, hal ini sulit juga untuk dipenuhi oleh pengetahuan tradisional yang umumnya hanya disampaikan secara lisan dan disampaikan ke generasi berikutnya secara turun-temurun. ${ }^{31}$

Dari berbagai penjelasan tersebut di atas bahwa secara substantif prinsip-prinsip hukum HKI belum cukup memadai untuk memberikan perlindungan terhadap karya intelektual yang berkarakter folklor/ EBT secara keseluruhan.

\section{d. Perlindungan EBT melalui Hukum Warisan Budaya}

Perlindungan EBT dimungkinkan pula melalui ketentuan hukum yangmengatur warisan budaya, karena pada dasarnya EBT merupakan bagian dari wujud warisan ${ }^{32}$ kebudayaan. ${ }^{33}$ Perlindungan terhadap warisan budaya dapat dilihat di dalam

\footnotetext{
${ }^{30}$ Miranda Risang Ayu, 2000, Konsep IG Dalam UUM di Indonesia Dalam Kaitannya Dengan Prinsip Proteksi Trip's, Bandung, FH Unpad, halaman 6, dalam Kholis Roisah, Perlindungan Ekspresi Budaya Tradisional Dalam Sistem Hukum Kekayaan Industri, Jurnal MMH, 2014.

${ }^{31}$ Tim Lindsey, dkk, opcit, halaman 263.

${ }^{32}$ Warisan (heritage) diartikan sebagai tradisi. Tradisi diartikan sebagai (a) sebuah warisan, yang didirikan, atau pola pikir adat, tindakan, atau perilaku (sebagai praktek agama atau kebiasaan soaial; (b) suatu keyakinan atau cerita atau badan kepercayaan atau cerita yang berhubungan dengan masa lalu yang
} 
Vol 1, No 1 (2018): Law \& Justice Journal, November 2018

konvensi-konvensi internasional yang bersifat legally binding ataupun beberapa deklarasi atau rekomendasi yang bersifat not legally binding yang diselenggarakan oleh organisasi PBB di bidang pendidikan, ilmu pengetahuan dan budaya atau United Nation of Education Scientific Cultural Organization (UNESCO), sebagai berikut :

1. UNESCOConvention Concerning the Protection of the World Cultural and Natural Heritage, 1972.

2. Convention on the Protection of the Archeological, Historical and Artistic Heritage of the Americans Nation, San Salvador 1976

\section{PEMBAHASAN}

\section{Defensive Protection terhadap Traditional Cultural Expressions (TCE) atau WBTB yang Dimiliki oleh Masyarakat di Kabupaten Blora.}

\section{a. Deskripsi keberadaan EBT/WBTB yang dimiliki oleh masyarakat di Kabupaten Blora}

EBT dari Kabupaten Blora Jawa Tengah sebagai bagian dari kekayaan bangsa dan negara Indonesia serta identitas maupun aset nasional keberadaannya perlu dipelihara, dipertahankan, dikembangkan, dilindungi, dipromosikan, dilestarikan dan dimanfaatkan baik dalam skala lokal, nasional maupun internasional. Dari penelitian di lapangan melalui pengamatan, observasi, wawancara dengan komunitas masyarakat diKabupaten Blora $^{34}$,dan dengan melakukan inventarisasi serta keberadaan EBT ada perbedaannya dengan tradisi dan norma adat diantara pemelihara EBT tersebut. Berikut inventarisasi WBTB di masyarakat Blora sebagai berikut :

\footnotetext{
umumnya diterima sebagai historis meskipun tidak dapat diverifikasi, yang penyebaran informasi, kepercayaan dan kebiasaan dari mulut ke mulut atau dari satu generasi ke generasi tidak tertulis; kontinuitas budaya dalam sikap sosial, adat istiadat, dan institusi; secara karakteristik, metode atau gaya, http://www. Merriam-webster.com/dictionary/heritage, diakses pada tanggal 18 Juli 2017.

${ }^{33}$ Koentjaraningrat, 1974, Mentalitet dan Pembangunan, Jakarta, PT Gramedia Pustaka Utama, Cetakan ke 21, halaman 6: "Kebudayaan paling sedikit mempunyai 3 wujud, yaitu (a) wujud kebudayaan sebagai suatu kompleks ide-ide, gagasan, nilai-nilai, norma-norma, peraturan dan sebagainya; (b) wujud kebudayaan sebagai suatu kompleks aktivitas kelakuan berpola dari manusia dalam masyarakat; (c) Wujud kebudayaan sebagai benda-benda hasil karya manusia. Ketiga wujud ini tidak terpisahkan satu sama lain. Kebudayaan lokal dan adat istiadat mengatur dan memberi arah kepada perbuatan dan karya manusia. Baik pikiran-pikiran maupun perbuatan dan karya manusia, menghasilkan benda dan kebudayaan fisiknya.

${ }^{34}$ Wawancara, Adi, Risang Guntur Seto, Ketua Klaster Seni Barongan, Blora, 13 Juni 2017, jam 15.20.
} 


\section{b. Ekspresi Budaya Ragam Seni Musik Rakyat Tradisional}

1) Kentrung merupakan sastra lisan yang hidup di beberapa daerah, antara lain di Tuban, Kediri dan juga Blora. Seni kentrung ini telah ditetapkan sebagai warisan budaya tak benda pada tahun 2013 dan telah dicatat dengan nomor sertifikat : 003380.

2) Kothekan lesung berasal dari bunyi yang dihasilkan oleh pemukulan alu pada lesung, yang dimainkan oleh sekelompok wanita desa pada waktu-waktu tertentu.

3) Seni hadroh sebagai bagian dari sejarah dan perkembangan Nahdatul Ulama.

4) Hadroh bukan saja berkembang di pesantren tetapi juga di kampus-kampus. Sebagai seni bernuansa islam hadroh harus berkembang dan menjadi media dakwah yang bermakna.

5) Jedoran adalah musik bernuansa Islami menggunakan peralatan musik tradisional seperti rebana dan beduk ketika tampil memenuhi undangan warga.

6) Seni tayub merupakan salah satu bentuk tari rakyat tradisional yang sangat populer di Jawa. Seni pertunjukkan sejenis ini juga dikenal dengan berbagai sebutan yaitu: ronggeng, gandrung, lengger, tandhak, dsb. Pertunjukkan tayub di Jawa merupakan tradisi yang sangat tua. Istilah tayub sudah dikenal pada masa Jawa Kuno abad ke-12, seperti yang tersebut dalam Kakawin Ghatotkacasraya, dijelaskan kata anayub atau nayub mirip dengan istilah tayub. Pertunjukkan tayub menghadirkan seorang penari perempuan yang menari dan menyanyi (menyinden). Pertunjukkan tayub di Blora tampaknya memiliki keterkaitan dengan rangkaian peperangan yang dilakukan oleh Raden Mas Said, yang kemudian menjadi adipati di Mangkunegaran (abad 18). Seni tayub ini telah ditetapkan sebagai warisan budaya tak benda pada tahun 2013 dan telah dicatat dengan nomor sertifikat : 003415.

\section{c. Ekspresi Budaya Wayang}

1) Wayang kulit purwa merupakan salah satu pertunjukkan wayang yang paling populer di Jawa, yang menyajikan sejumlah repertoar lakon dari wiracarita Ramayana dan Mahabharata. Pentas/pagelaran wayang ini diselenggarakan dalam rangka Peringatan Hari Jadi Blora tanggal 11 Desember setiap tahunnya. Selain itu ditampilkan jugapada peringatan 1 Muharrom/ 1 Suro tiap tahun di Kelurahan Mlangsen dan 
pertapaan Wringin Seto.Begitu pula setiap malam Jum'at Pon di Pendopo Rumah Dinas Bupati Blora. ${ }^{35}$

2) Wayang krucil menurut pendapat orang Blora dekat sekali dengan pengertian kecil, biasanya dibuat dari kayu yang rata-rata ukurannya kecil. Di dalam klasifikasi seni pertunjukkan, wayang krucil Blora dapat digolongkan ke dalam kesenian klasik, dan di dalamnya tercantum unsur-unsur kerakyatan yang serasi. Wayang krucil ini telah ditetapkan sebagai warisan budaya tak benda pada tahun 2016 dan telah dicatat dengan nomor sertifikat : 6338 .

Perlindungan hukum adalah suatu perlindungan yang diberikan kepada subyek hukum sesuai dengan aturan hukum, baik itu yang bersifat preventif (pencegahan) maupun dalam bentuk represif (pemaksaan).

Defensive protection atau strategi defensif dalam perlindungan $\operatorname{EBT}(T C E)$ berfungsi untuk mencegah penerapan rezim HKI terhadap warisan budaya tradisional, sehingga warisan budaya Blora tetap berada di dalam ranah publicdomain ( dapat digunakan secara luas oleh masyarakat) sebagai warisan budaya milik bersama tanpa ada satu pihakpun yang mengklaim hak-hak eksklusif atasnya. Bentuk perlindungan ini lebih berfokus pada pelestarian nilai-nilai budaya yang terkandung dalam kreativitas intektual tradisional yang hidup di tengah masyarakat yang tujuannya menjaga keutuhan nilai-nilai budaya yang hidup di tengah masyarakat. Perlindungan hukum pada karya EBT berada dalam ranah hukum warisan budaya dengan melakukan inventarisasi secara terbuka dalam sebuah database sebagai konsekwensi dari common heritage of mankind (warisan bersama umat manusia) yang merupakan asas dalam hukum Internasional bahwa wilayah teritorial dan elemen warisan umum manusiawi (budaya dan alam) harus diadakan dengan kepercayaan untuk generasi depan dan dilindungi dari eksploitasi negara atau perusahaan nasional. ${ }^{36}$

\section{d. Kategori Warisan Budaya Takbenda Indonesia}

Mengacu pada Konvensi UNESCO Tahun 2003 tentang Safeguarding of Intangible Cultural Heritage yang disebut warisan budaya takbenda dibagi atas lima domain :

1) Tradisi dan ekspresi lisan

\footnotetext{
${ }^{35}$ Buku Panduan Wisata Kabupaten Blora Tahun 2017, Dinas Kepemudaan, Olahraga, Kebudayaan dan Pariwisata Kabupaten Blora, halaman 24.

${ }^{36}$ Wikipedia.org/wiki/c0mmc
} 
2) Seni pertunjukan

3) Adat istiadat masyarakat, ritus, dan perayaan-perayaan

4) Pengetahuan dan kebiasaan perilaku mengenai alam semesta

5) Keterampilan dan kemahiran kerajinan tradisional

Di bawah ini daftar rekapitulasi Penetapan Warisan Budaya Takbenda Indonesia(WBTB)/EBT/ TCEs/ Intangible Cultural Heritage (ICH) sesuai Konvensi UNESCO Tahun 2003 Masyarakat Di Kabupaten BLORA. Selama tahun 2013-2016 terdapat 16 penetapan warisan budaya takbenda Indonesia, sementara masih banyak WBTB di masyarakat Blora yang masih dalam proses penetapan ( barong) dan bahkan banyak yang belum ditetapkan, antara lain motif/desain batik Blora.

Rekapitulasi Penetapan Warisan Budaya Tak benda Indonesia (WBTB)/EBT/TCEs/ Intangible Cultural Heritage (ICH)sesuai Konvensi UNESCO Tahun 2003 Masyarakat Di Kabupaten BLORA pada periode Tahun 2013-2016 per tanggal 16-6-2017, dijelaskan melalui tabel berikut;

Tabel 1:

\begin{tabular}{|c|c|c|c|c|}
\hline No. & Tahun & $\begin{array}{l}\text { Nomor } \\
\text { Sertifikat: }\end{array}$ & Nama Karya Budaya: & $\begin{array}{ll}\text { Domain } & \text { EBT/ICH } \\
\text { Katagori : } & \\
\end{array}$ \\
\hline 1. & 2013 & 003369 & Asal usul nama Blora & Tradisi dan ekspresi lisan \\
\hline 2. & 2013 & 003371 & Bahasa orang Samin/ & \\
\hline 3. & 2013 & 00380 & Seni Kentrung Blora & Seni Pertunjukan \\
\hline 4. & 2013 & 003415 & $\begin{array}{l}\text { Kesenian Tayub Blora } \\
\text { Wayang Krucil }\end{array}$ & \\
\hline 5. & 2016 & 6338 & & \\
\hline 6. & 2010 & 000003 & $\begin{array}{l}\text { Agama adam religi orang } \\
\text { Samin di Jawa Tengah } \\
\text { Perkawinan masyarakat }\end{array}$ & $\begin{array}{l}\text { Adat istiadat masyarakat, } \\
\text { ritus, dan perayaan- } \\
\text { perayaan }\end{array}$ \\
\hline 7. & 2013 & 003418 & $\begin{array}{l}\text { Samin } \\
\text { Kompleks makam Bupati }\end{array}$ & \\
\hline 8. & 2013 & 003907 & Blora & \\
\hline 9. & 2014 & 004592 & esa Blora & \\
\hline $\begin{array}{l}10 . \\
11 .\end{array}$ & $\begin{array}{l}2016 \\
2013\end{array}$ & $\begin{array}{l}006721 \\
003400\end{array}$ & $\begin{array}{l}\text { Mantu Kucing } \\
\text { Dokar Blora }\end{array}$ & $\begin{array}{l}\text { Pengetahuan } \\
\text { kebiasaan }\end{array}$ \\
\hline
\end{tabular}


Vol 1, No 1 (2018): Law \& Justice Journal, November 2018

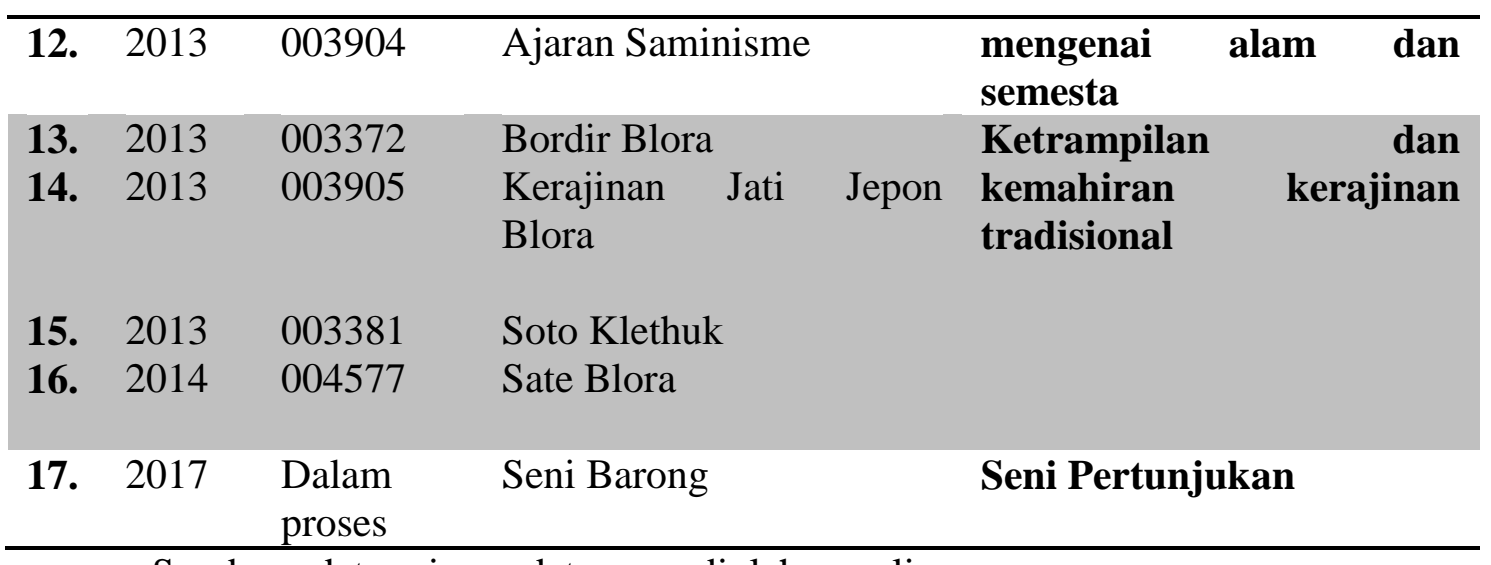

Sumber : data primer, data yang diolah penulis.

Alur Proses Pencatatan, Penetapan Dan Pengusulan Warisan Budaya Takbenda Indonesia

Proses pencatatan, penetapan dan pengusulan dapat digambarkan dalam bagan alir berikut ini :

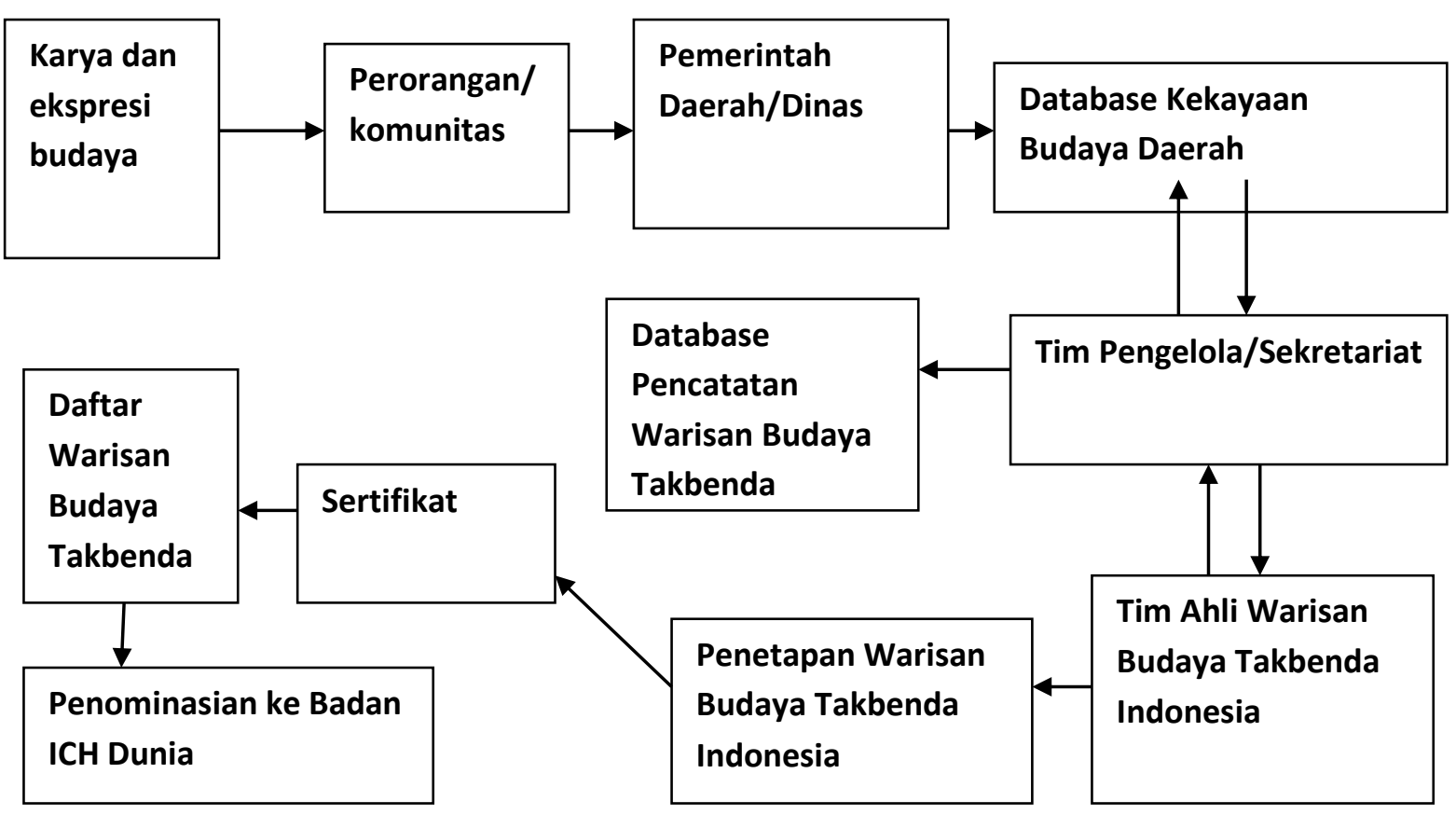




\section{Karya budaya batik Blora yang perlu dilakukan proses pencatatan, penetapan dan pengusulan WBTB Indonesia di Masyarakat Blora}

Seni batik sebagai kreativitas intelektual kekayaan budaya masyarakat asli Indonesia yang sangat beragam dan dipengaruhi oleh letak geografis, kondisi alam sekitar, kepercayaan dan kontak dengan kultur budaya lain. Klasifikasi seni batik dapat dilihat dari aspek asal daerah pembatikan yang kemudian menghasilkan ragam hias, tata warna yang merupakan cerminan dari daerah asal. Batik Blora menghasilkan pola/ ciri khasdesain pohon jati (daun jati, bunga/kembang jati/ bunga opo, batang/lingkar tahun pohon jati/kambium, biji jati/janggleng, ulat jati/ungker) dikenal dengan desain kroyokan dan dominan warna cerah. Batik Blora termasuk batik modern yang mencerminkan bentuk, motif, fungsi dan teknik produksi yang merupakan aspirasi budaya modern. ${ }^{37}$ Pada mulanya batik yang dikenal hanya batik tulis, seiring penggunaan batik yang semakin luas, teknologi batik berkembang pula dengan pesatnya, sehingga terdapat dua pengertian seni batik yaitu tradisional dan modern.

\section{Inventarisasi dan Dokumentasi Batik Blora}

Dalam rangka melindungi hak cipta bagi para pencipta motif batik, maka diperlukan suatu inventarisasi terhadap motif-motif batik kontemporer di setiap daerah. Berikut ini merupakan inventarisasi batik Blora, yang diperoleh dari 4 pengrajin batik di wilayah Blora kota. Dari inventarisasi tersebut didapati bahwa tata warna batik Blora dominan warna primer (jreng) yaitu merah, pink, biru, hijau dan sebagainya, dengan desain "kroyokan" yang menampilkan motif khas batik Blora berupa desain pohon jati (daun jati, bunga/kembang jati/ bunga opo, batang/lingkar tahun pohon jati/kambium, biji jati/janggleng, ulat jati/ungker). Dalam penelitian ditemukan 58 motif batik Blora hingga tahun 2017.

\section{Lembaga Pelaksana/Penanggung Jawab/Pemangku Kepentingan}

Idealnya proses inventarisasi/ pendataan / pencatatan, penetapan dan pengusulan kekayaan budaya tak benda dilakukan oleh lembaga pelaksana yang secara implisit disebutkan sebagai lembaga representasi negara dalam hal ini dengan mengoptimalkan Direktorat Jendral Kementerian Pendidikan dan Kebudayaan dalam hal ini Direktorat

\footnotetext{
${ }^{37}$ Afrillyana Purba, 2005, Trip's WTO dan Hukum HKI Indonesia Kajian Perlindungan Hak Cipta Seni Batik Tradisional Indonesia, Jakarta: Rineka Cipta, halaman 44-45.
} 
Warisan dan Diplomasi Indonesia Direktorat Jenderal Kebudayaan. Selain itu perlu ditumbuhkan semangat bagi masyarakat luas untuk melakukan proses inventarisasi ini. Hal ini membutuhkan tenaga yang ekstra keras mengingat beberapa elemen mempunyai pandangan yang berbeda mengenai konsep folklor ini.

Dalam hal ini terdapat beberapa strategi ${ }^{38}$ yang dapat dilakukan oleh seluruh unsur masyarakat sesuai dengan peran dan fungsinya masing-masing, sehingga proses inventarisasi ini tidak hanya dibebankan sepenuhnya kepada pemerintah. Pertama adalah memberikan pemahaman kepada masyarakat adat dan para seniman maupun pengusaha mengenai arti penting pengetahuan traditional dan ekspresi budaya tradisional.

Kedua adalah memanfaatkan kesenian tradisional secara optimal dengan menghormati hak-hak sosial dan budaya masyarakat yang berkepentingan. Ketiga adalah melakukan dokumentasi yang komprehensif. Dokumetasi digital yang memadai diakses oleh pihak lain atas pengetahuan tradisional dan ekspresi budaya tradisional di Indonesia tersebut berfungsi sebagai mekanisme perlindungan defensif (defensiveprotection) untuk menanggulangi penyalahgunaan (misappropriation) instrumen HKI terhadap folklor Indonesia di luar negeri. ${ }^{39}$ Dokumentasi ini yang kemudian dipakai oleh para advokat Indonesia sebagai dasar pembuktian bahwa suatu kesenian yang didaftarkan atau dimanfaatkan di luar negeri adalah tidak orisinal sebagaimana dipersyaratkan dalam hukum hak cipta internasional. Dalam kasus lagu rasa sayange misalnya, jika Indonesia memiliki dokumen yang mendukung lagu tersebut sebagai lagu tradisioanl Indonesia yang sudah dipraktekkan sejak lama, maka sudah didapatkan dasar gugatan yang memadai. Pada akhirnya setiap langkah yang dilakukan membutuhkan dukungan pemerintah sehingga tercipta upaya yang komprehensif, sistematis dan berkelanjutan, Sementara pemerintah harus menjadi ujung tombak proses dokumentasi dan pengajuan gugatan terhadap setiap pihak asing sekaligus mengembangkan harkat dan martabat sosial budaya Indonesia baik pada tingkat domestik maupun internasional.

\footnotetext{
${ }^{38}$ M.Ajisatria Suleiman, 2008, Kesenian Tradisional Adalah Kekayaan Intelektual Bangsa,artikel hukum.blogspot.co.id, diakses 6 Agustus 2017.

${ }^{39} \mathrm{Ibid}$, halaman 147-148.
} 


\section{Upaya agar tidak terjadi penggunaan secara melawan hukum (misappropriation)} terhadap traditional cultural expressions (TCE) yang dimiliki masyarakat di Kabupaten Blora oleh pihak lain

Misappropriation diartikan sebagai satu usaha untuk meggunakan atau memanfaatkan pengetahuan tradisional oleh pihak asing secara melawan hukum. Dalam Black's Law Dictionary disebutkan bahwa misappropriation dalam kaitannya dengan HKI adalah "using the non-copyrightable information or ideas that an organization, or copying a work whose creator has not yet claimed or been granted exclusive rights in the work". 40

Terselenggaranya inventarisasi dan dokumentasi diharapkan mampu memperjelas identitas kebudayaan suatu EBT yang ada dan hidup di Indonesia sekaligus menjamin keberlangsungannya. Pemerintah daerah perlu mengatur pembagian manfaat (benefit sharing) dengan warga masyarakat lokal serta melakukan dokumentasi terhadap EBT yang sudah ada.

Inventarisasi merupakan salah satu langkah Defensive Protection, dimaksudkan sebagai upaya agar tidak terjadi penggunaan secara melawan hukum terhadap EBT tertentu yang dimiliki oleh masyarakat Blora. Langkah-langkah yang dilakukan dengan membangun database yang dapat digunakan sebagai proses akhir inventarisasi yang kemudian didokumentasikan secara sistematis dalam sebuah database tersebut. ${ }^{41}$

Pemerintah telah mengeluarkan buku panduan tentang pencatatan, penetapan dan pengusulan warisan budaya tak benda Indonesia melalui Direktorat Warisan dan Diplomasi Budaya Direktorat Jenderal Kebudayaan Kementerian Pendidikan dan Kebudayaan tahun 2015. Maksud dan tujuan ini sebagai acuan bagi pemangku kepentingan (orang, komunitas budaya, masyarakat hukum adat, badan usaha dan pemerintah daerah) dalam melaksanakan kegiatan pencatatan, penetapan, dan pengusulan Warisan Budaya Takbenda Indonesia. Sedangkan tujuan disusunnya panduan ini untuk memberikan pemahaman, kesadaran, dan mengajak masyarakat

\footnotetext{
${ }^{40}$ Lihat Bryan A Gamer (Editor in Chief), 2004, Black's Law Dictionary, Edisi ke 8, St Paul Minn: Thomson West, halaman 1019.

${ }^{41}$ Arif Lutviansori, 2010, Hak Cipta dan Perlindungan Folklor di Indonesia, Yogjakarta, Graha Ilmu,halaman146.
} 
melestarikan warisan budaya takbenda, memberikan pemahaman kepada seluruh pemangku kepentingan tentang prosespencatatan, penetapan dan pengusulan warisan budaya tak benda Indonesia. Sebagai dasar hukum dari kegiatan ini adalah UUDRI Tahun 1945, amandemen keempat, 2002, Pasal 32 (1), Undang-Undang Nomor 28 Tahun 2014, tentang Hak Cipta,Undang-Undang Nomor 5 /2017 tentang UndangUndang Pemajuan Budaya, Perpres Nomor 78 Tahun 2007 tentang Konvensi untuk Perlindungan Warisan Budaya Takbenda, Peraturan Bersama Mendagri dan Mendikbud dan Pariwisata Nomor 42 Tahun 2009 tentang Panduan Pelaksanaan Tugas dan Kewajiban Pemerintah Daerah dalam Pelestarian Kebudayaan, Peraturan Mendikbud R I Nomor 106 Tahun 2013 tentang Warisan Budaya Takbenda Indonesia.

\section{KESIMPULAN}

1. Perlindungan defensif ( Defensive Protection) ini berada di luar kerangka hukum HKI, dan lebih berfokus untuk mencegah agar warisan budaya pada umumnya dan EBT pada khususnya tidak hilang atau punah. Tujuannya untuk menjaga keutuhan nilai-nilai budaya yang hidup sambil tetap menjaga integritas dan keberadaan EBT tersebut dalam ranahpublic domain yang dapat diakses dan digunakan siapa saja dan dinikmati oleh generasi yang akan datang. Inventarisasi merupakan salah satu langkah Defensive Protection, dimaksudkan sebagai upaya agar tidak terjadi penggunaan secara melawan hukum terhadap EBT tertentu yang dimiliki oleh masyarakat Blora.

2. Dokumentasi dapat berupa rekaman, manuscript (naskah) atau laporan penelitian dengan melibatkan segenap elemen akademisi, peneliti, praktisi di bidang hukum, kesenian, musikologi, antropologi, jurnalisme, budaya, lembaga swadaya masyarakat, elemen masyarakat sipil lainnya yang memegang peranan vital dalam mewujudkannya. Dokumetasi digital yang memadai diakses oleh pihak lain atas pengetahuan tradisional dan ekspresi budaya tradisional di Indonesia tersebut berfungsi sebagai mekanisme perlindungan defensif (defensiveprotection) untuk menanggulangi penyalahgunaan (misappropriation) instrumen HKI terhadap folklor Indonesia di luar negeri. Untuk menekan biaya dokumentasi partisipasi masyarakat juga harus dibuka seluas-luasnya sehingga data dan informasi dapat diperoleh dari berbagai sumber. 
Saran :

1. Indonesia membutuhkan pengaturan perlindungan terhadap EBT/WBTB secara khusus sesuai dengan karakteristik dari pengetahuan tradisional dan ekspresi budaya tradisional yang didasarkan pada kearifan lokal agar supaya melindungi warisan budaya secara umum dan EBT/WBTB secara khusus dari punahnya karya budaya yang bersangkutan oleh pihak lain.

2. Pemerintah sebaiknya mendukung perlindungan EBT melalui identifikasi dan dokumentasi semua karya pengetahuan tradisional dan ekspresi budaya tradisional di Indonesia dan setiap langkah membutuhkan dukungan pemerintah baik pusat, daerah, kabupaten/kota sampai ke tingkat desa/ Kelurahan serta RW/RT sampai komunitas/masyarakat sebagai pelaku budaya, yang memiliki kewajiban dan melaporkan pelaksanaan kebijakan, program, pencatatan WBTB Indonesia di daerah pada Direktorat Warisan dan Diplomasi Budaya Dirjen Kemendikbud sehingga terjadi penguatan jati diri bangsa Indonesia.

\section{DAFTAR PUSTAKA}

Afrillyanna Purba, dkk., 2005, TRIPs-WTO Dan Hukum HKI Di Indonesia Kajian Perlindungan Hak Cipta Seni Batik Tradisional Indonesia, Jakarta: Asdi Mahasatya.

Arif Lutfiansori, 2010, Hak Cipta Dan Perlindungan Folklore Di Indonesia, Yogyakarta: Graha Ilmu.

Ayu, Miranda Risang, 2000, Konsep IG Dalam UUM di Indonesia Dalam Kaitannya Dengan Prinsip Proteksi Trip's, Bandung, FH Unpad.

Ayu, Miranda Risang, Harry Alexander, Wina Puspitasari, 2010, Hukum Sumber Daya Genetik, Pengetahuan Tradisional dan EBT, Bandung, Alumni.

Bayu Akbar W, 2016, Perlindungan Hukum Terhadap EBT oleh Negara Sebagai Pemegang Hak Cipta Kekayaan Komunal Masyarakat, FH Unsoed.

Bryan A Gamer (Editor in Chief), 2004, Black's Law Dictionary, Edisi ke 8, St Paul Minn: Thomson West.

Budi Agus Riswandi, Direktur Pusat HKI FH UII Jogjakarta dalam Arif Lutfiansori, 2010, Hak Cipta Dan Perlindungan Folklore Di Indonesia, Yogyakarta: Graha Ilmu.

Convention on Biological Diversity1992(CBD) 5 Juni 1992 telah diratifikasi oleh Indonesia dengan Undang-Undang Nomor 5 Tahun 1994 tentang Pengesahan United Nations Convention on Biological Diversity (Konvensi Perserikatan Bangsa-Bangsa mengenai Keanekaragaman Hayati) (LN.1994-41,TLN No.3556). 
Document WIPO/GRTKF/IC/6//6/3, no 37.

Eddy Damian, 2012, Glosarium Hak Cipta dan Hak Terkait, Bandung, Alumni.

Edy Sedyawati, 2003, Budaya Indonesia Kajian Arkeologi, Seni dan Sejarah, PT Rajawali Pers, Jakarta.

Heru Irianto dan Burhan Bungin, "Pokok-Pokok Penting tentang Wawancara" dalam Burhan Bungin (editor), Metodologi Penelitian Kualitatif Aktualisasi Metodologis ke Arah Ragam Varian Kontemporer, 2001, Jakarta : Raja Grafindo Perkasa.

James Danandaja, 1991, Folklor Indonesia Ilmu Gosip, dongeng dan lain-lain, Jakarta: Pustaka Utama Grafiti, Cetakan ketiga.

Jan Harold Brunvand, 1978, The Study of American Folklor an Introduction, 2nd, New York, W.W. Norton \&Co Inc dalam James Danandjaya, 1991, Folklor Indonesia Ilmu Gosip, dongeng dan lain-lain, Jakarta: Pustaka Utama Grafiti, Cetakan ketiga.

Kholis Roisah,2014, Perlindungan Ekspresi Budaya Tradisional Dalam Sistem HKI, Jurnal MMH, Jilid 43 Nomor:3.

2014, Perlindungan Ekspresi Budaya Tradisional Dalam Sistem Hukum Kekayaan Industri, Jurnal MMH.

Koentjaraningrat, 1974, Mentalitet dan Pembangunan, Jakarta, PT Gramedia Pustaka Utama, Cetakan ke 21.

Lexy J.Moleonf, 2007, Metode Penelitian Kualitatif, Bandung, Remaja Rosda Karya.

Rahmi Janet, 2014, Hukum Hak Cipta (Copyright's Law), Bandung, PT Citra Aditya Bakti.

Silk von Lewinski, 2007, Indigenous Heritage and IP, GRTKF 2nd Edition, Wolter Kluwer, Law and Business Netherland.

Soerjono Soekanto dkk, 1988, Pendekatan Sosiologi Terhadap Hukum, Jakarta, PT Bina Aksara.

Sudarto, 2002, Metode Penelitian Filsafat, Jakarta, Raja Grafindo.

Tim Lindsey, dkk, Hak Kekayaan Intelektual SuatuPengantar

WIPO Secretariat, Consilidated Analysis of The Legal Protection of Traditional Cultural Expression/Expression of Folklore.

William R.Bascom dalam James Danandjaya, 1991, Folklor Indonesia Ilmu Gosip, dongeng dan lain-lain, Jakarta: Pustaka Utama Grafiti, Cetakan ketiga.

\section{Peraturan dan Perundang-Undangan:}

Deklarasi Universal Hak Asasi Manusia (Universal Declaration of Human Rights / DUHAM 1948.

Konvensi Bern Pasal 6 bis, Moral Rights.

Undang-Undang Nomor 28 Tahun 2014, Hak Cipta.

Undang-Undang Nomor 5 Tahun 2017, Undang-Undang Tentang Pemajuan Kebudayaan.

Perpres Nomor 78 Tahun 2007 tentang Konvensi untuk Perlindungan Warisan Budaya Takbenda.

Peraturan Bersama Mendagri dan Mendikbud dan Pariwisata Nomor 42 Tahun 2009 tentang Panduan Pelaksanaan Tugas dan Kewajiban Pemerintah Daerah dalam Pelestarian Kebudayaan. 
Peraturan Mendikbud R I Nomor 106 Tahun 2013 tentang Warisan Budaya Takbenda Indonesia.

Buku Panduan Wisata Kabupaten Blora Tahun 2017, Dinas Kepemudaan, Olahraga, Kebudayaan dan Pariwisata Kabupaten Blora.

Penetapan Warisan Budaya Tak Benda Indonesia, 2013-2116, Direktorat Warisan dan Diplomasi Budaya Dirjen Kebudayaan Kemendikbud.

\section{Website: -}

Ignatius Haryanto, 2009, Dilema Kebudayaan Dalam Era HKI, www//http; kombinasi; net/dilema-kebudayaan-tradisional-di era hki, posted 01/05/2009. Mencari Format Kebijakan Hukum Yang Sesuai Untuk Perlindungan Folklor di Indonesia, di Indonesia, diakses pada Selasa, 21 Agustus 2017, pukul 16.07. Merriam-webster.com/dictionary/heritage, http://www; diakses pada tanggal $18 \mathrm{Juli}$ 2017.akses pada Selasa, 21 Agustus 2017, pukul 16.07.

Ninuk Mardiana Pambudy, Avontur 24 jam Blora, Kompas, Minggu, 9 Juli 2017. 